\title{
APPENDICULA NICOBARICA (ORCHIDACEAE - EPIDENDROIDEAE - PODOCHILEAE), A NEW SPECIES FROM GREAT NICOBAR BIOSPHERE RESERVE, INDIA
}

\author{
J. Jayanthi, R. Sumathi, K. Karthigeyan \& D. Narasimhan
}

Appendicula nicobarica Jayanthi, Sumathi \& Karthig. (Orchidaceae) is described and illustrated from Great Nicobar Biosphere Reserve, India.

Keywords. Appendicula, Great Nicobar Island, Orchidaceae.

\section{INTRODUCTION}

The genus Appendicula Blume (Orchidaceae) comprises about 60 species (Pridgeon et al., 2005) distributed from India to China (Hainan), Taiwan and Hong Kong southeastwards through Thailand to Malaysia and Indonesia, the Philippines, New Guinea and the southwest Pacific islands (Seidenfaden, 1986; Seidenfaden \& Wood, 1992; Comber, 2001; Pridgeon et al., 2005). Two species have been recorded from India, namely Appendicula cornuta Blume from the Sikkim Himalayan region and A. reflexa Blume from Great Nicobar Island (Sathish Kumar \& Manilal, 1994).

During a survey of the flora of Campbell Bay National Park in the Great Nicobar Biosphere Reserve, a good population of an undetermined species of Appendicula was found growing in the evergreen forest on Mount Thullier, the highest peak on Great Nicobar Island. Consultation of the literature and comments from experts revealed that this taxon is new to science, and it is described below.

\section{SPECIES DESCRIPTION}

Appendicula nicobarica Jayanthi, Sumathi \& Karthig., sp. nov. Fig. 1.

Appendiculae pendulae Blume affinis, foliis minoribus (ad $5 \mathrm{~cm}$ longis, $1.2 \mathrm{~cm}$ latis), inflorescentia tantum terminali eramosa, bracteis minoribus (3-5 mm longis, c. $3 \mathrm{~mm}$ latis), floribus minoribus (ad $4.5 \mathrm{~mm}$ longis), mento breviore (ad $2 \mathrm{~mm}$ longo), labello angustiore (ad $2.2 \mathrm{~mm}$ lato) prominentiter recurvato, epichilio sine carinis lateralibus et callo differt. - Type: India, Great Nicobar Island, Campbell Bay National Park, Mount Thullier, 30 v 2002, Jayanthi, Sumathi \& Karthigeyan 19343 (holo CAL; iso PBL). 


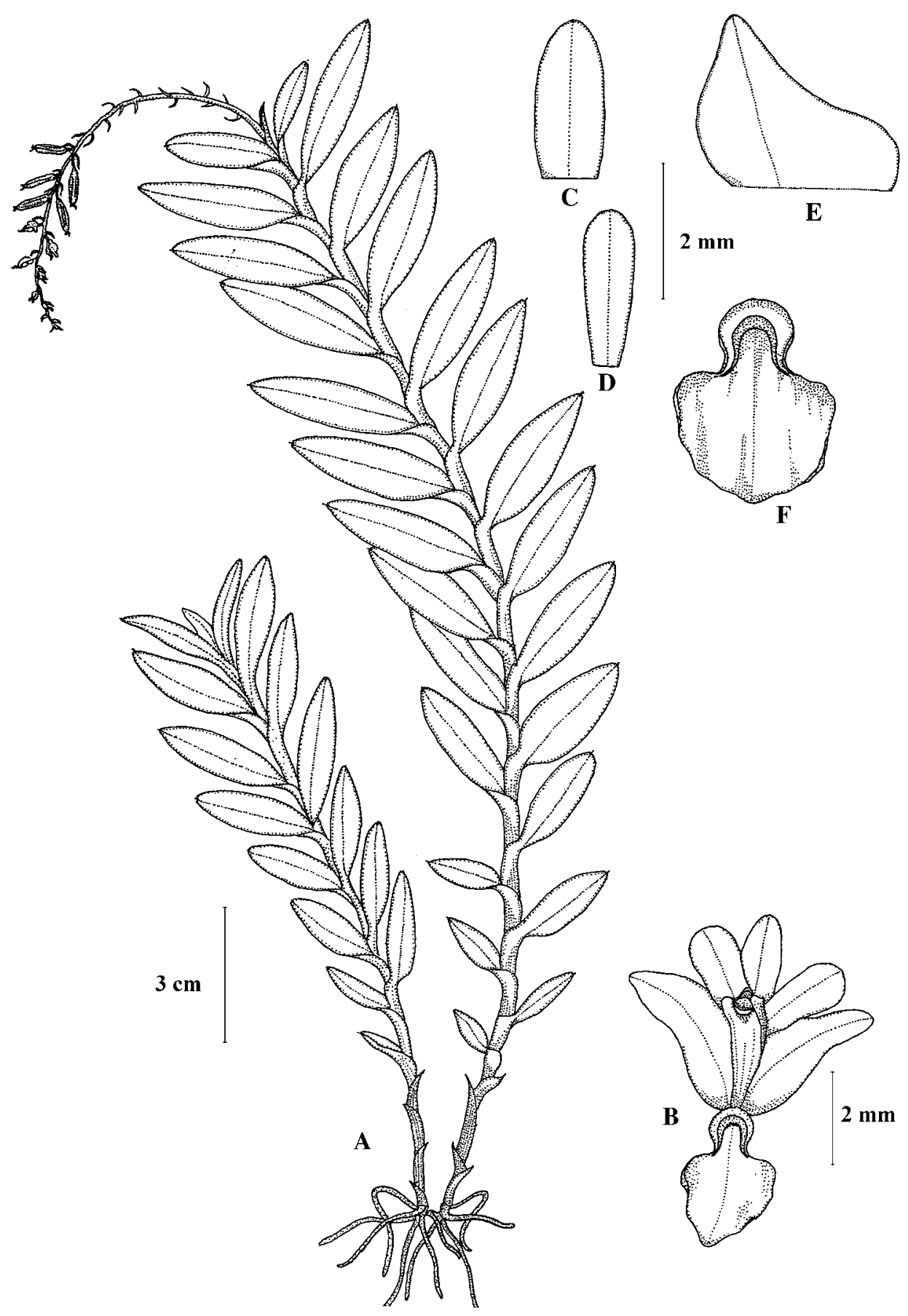

FIG. 1. Appendicula nicobarica Jayanthi, Sumathi \& Karthig. A, habit; B, flower; C, dorsal sepal; D, petal; E, lateral sepal; F, lip. 
Epiphytic herb 25-60 cm high. Rhizome short. Roots c. $0.2 \mathrm{~mm}$ in diameter, fibrous, covered by dense hairs. Stems erect, $20-50 \mathrm{~cm}$ long, $0.2-0.4 \mathrm{~cm}$ in diameter, simple, entirely covered by leaf-sheaths. Leaves $2-5 \times 0.4-1.2 \mathrm{~cm}$, alternate, distichous, membranous, narrowly elliptic-oblong, sheathed at base, apex bilobed, margin entire, glabrous, mid-nerve prominent, extending above the leaf apex and forming an c. $1 \mathrm{~mm}$ long cusp; sheath $0.5-1 \mathrm{~cm}$ long. Inflorescence terminal, $3-11 \mathrm{~cm}$ long, simple, arising from the sheath of the apical leaf, few-flowered; floral bracts 3-5 $\times 2-$ $3 \mathrm{~mm}$, ovate-lanceolate, apex long acuminate, glabrous, 5-nerved, reflexed. Flowers up to $4.5 \mathrm{~mm}$ long, greenish yellow, lip creamy-white. Pedicel-with-ovary up to $4 \times$ $1 \mathrm{~mm}$. Dorsal sepal c. $2.3 \times 1 \mathrm{~mm}$, elliptic-oblong, apex rounded-obtuse, margin entire, 1-nerved. Lateral sepals c. $2.3 \times 3 \mathrm{~mm}$, obliquely ovate-triangular, apex obtuse, margin entire, 1-nerved. Mentum c. $2 \mathrm{~mm}$ long. Petals c. $2.3 \times 1 \mathrm{~mm}$, oblongobovate, apex rounded, margin entire, 1-nerved. Lip $3 \times 2.2 \mathrm{~mm}$, fleshy, recurved, obovate; basal appendage concave, fleshy, swollen at the centre, with 2 tapering edges. Column c. $2.5 \times 0.5 \mathrm{~mm}$; anther-cap c. $1 \times 1 \mathrm{~mm}$, broadly elliptic-rhomboid; pollinia 6. Capsule c. $8 \times 3 \mathrm{~mm}$, 6-ribbed, dehiscing by longitudinal slits.

Distribution. India: Great Nicobar Island.

Habitat and ecology. Well-shaded, moist inland evergreen forest; epiphytic on mosscovered trunks of Kibara coriacea (Blume) Tulasne and Gironniera subaequalis Planch.; above $600 \mathrm{~m}$. Flowering and fruiting: May and June.

Etymology. The specific epithet refers to the type locality, Great Nicobar Island.

Appendicula nicobarica resembles the widespread A. pendula Blume in habit, but differs in having shorter simple stems, smaller leaves (up to $5 \mathrm{~cm}$ long), smaller inflorescences (up to $11 \mathrm{~cm}$ long), smaller broadly ovate-lanceolate floral bracts $(3-5 \times$ 2-3 mm), smaller flowers (up to $4.5 \mathrm{~mm}$ long) with a $2 \mathrm{~mm}$ long mentum, and a prominently recurved lip lacking lateral keels and callus on the epichile. The distinguishing characters between Appendicula pendula and A. nicobarica are provided in Table 1.

TA B L 1. Characters distinguishing Appendicula nicobarica and A. pendula

\begin{tabular}{|c|c|c|}
\hline Character & Appendicula nicobarica & Appendicula pendula \\
\hline Stems & $25-60 \mathrm{~cm}$ long, unbranched & Up to $2 \mathrm{~m}$ long, branched \\
\hline Leaves & Less than $1 \mathrm{~cm}$ apart, $2-5 \mathrm{~cm}$ long & c. $2 \mathrm{~cm}$ apart, 5-12 cm long \\
\hline Inflorescence & $\begin{array}{l}\text { Only terminal, up to } 11 \mathrm{~cm} \text { long, } \\
\text { not pendulous }\end{array}$ & $\begin{array}{l}\text { Both terminal and lateral, up to } \\
18 \mathrm{~cm} \text { long, pendulous }\end{array}$ \\
\hline Floral bracts & $\begin{array}{l}\text { Broadly ovate to lanceolate, } \\
3-5 \times 2-3 \mathrm{~mm}\end{array}$ & Oblong to lanceolate, c. $6 \times 5 \mathrm{~mm}$ \\
\hline Flowers & c. $4.5 \mathrm{~mm}$ long & c. $6.5 \mathrm{~mm}$ long \\
\hline Dorsal sepal & c. $2 \times 1 \mathrm{~mm}$ & c. $4 \times 2.5 \mathrm{~mm}$ \\
\hline Lip & $\begin{array}{l}\text { Obovate, without reddish spots at } \\
\text { base, lateral keels and callus } \\
\text { absent on the epichile }\end{array}$ & $\begin{array}{l}\text { Oblong, with reddish spots at base, } \\
\text { lateral keels and callus present on } \\
\text { the epichile }\end{array}$ \\
\hline
\end{tabular}


A good population with more than 100 individuals was observed on the host trees at an elevation above $600 \mathrm{~m}$. According to the IUCN Standards and Petitions Working Group (2008) this species could be assigned to the Endangered category under the criteria B2a. However, there is no immediate threat to this population since it occurs in a protected biosphere reserve.

\section{ACKNOWLEDGEMENTS}

The authors are grateful to Dr M. Sanjappa, Director, Dr H. J. Chowdhery, Joint Director and Dr P. G. Diwakar, Botanical Survey of India for facilities; Dr Paul Ormerod for confirming the identity of the species; Dr J. F. Veldkamp, Nationaal Herbarium Nederland, Universiteit Leiden branch, for the Latin diagnosis; and Dr P. Dayanandan and Dr C. Livingstone, Madras Christian College, Tambaram, for encouragement.

\section{REFERENCES}

Com вer, J. B. (2001). Orchids of Sumatra. Malaysia: Natural History Publications (Borneo).

IUCN Standards and Petitions Working Group (2008). Guidelines for Using the IUCN Red List Categories and Criteria. Version 7.0. Prepared by the Standards and Petitions Working Group of the IUCN SSC Biodiversity Assessments Sub-Committee in August 2008. http://intranet.iucn.org/webfiles/doc/SSC/RedList/RedListGuidelines.pdf

Pridgeon, A. M., Cribi, P. J., Chase, M. W. \& Rasmussen, F. N. (2005). Genera Orchidacearum. Vol. 4: Epidendroideae (Part 1). Oxford: Oxford University Press.

Sathish Kumar, C. \& Manilal, K. S. (1994). A Catalogue of Indian Orchids. Dehra Dun: Bishen Singh Mahendra Pal Singh.

Seidenfaden, G. (1986). Orchid genera in Thailand XIII. Thirty-three epidendroid genera. Opera Bot. 89: 135-142.

Seidenfaden, G. \& Wood, J. J. (1992). The Orchids of Peninsular Malaysia and Singapore. Fredensborg: Olsen \& Olsen. 